\title{
Production, water-use efficiency and post-harvest quality of hydroponic mini watermelon under salinity stress ${ }^{1}$
}

\author{
Laís Monique Gomes do $\mathrm{O}^{2}$, Alide Mitsue Watanabe Cova², André Dias de Azevedo Neto ${ }^{3}$, \\ Marcela Ganda Souza ${ }^{2}$, Andressa Leite Santos ${ }^{2}$, Hans Raj Gheyi ${ }^{2}$
}

\section{ABSTRACT}

Irregularity or shortage of rainfall in semi-arid regions forces farmers to use low-quality water to irrigate crops. The present study aimed to assess the water-use efficiency and post-harvest quality of 'Sugar Baby' mini watermelon in response to different electrical conductivities of the nutrient solution [2.5 (control), 3.5, 4.5, 5.5 and $6.5 \mathrm{dS} \mathrm{m}^{-1}$ ], in a floating hydroponic system. The experimental design was completely randomized, with four replicates. The water consumption, production and water-use efficiency were evaluated, as well as qualitative and physico-chemical variables of the fruits. The total water consumption of the plants during the crop cycle varied between $43\left(6.5 \mathrm{dS} \mathrm{m}^{-1}\right)$ and $54\left(2.5 \mathrm{dS} \mathrm{m}^{-1}\right) \mathrm{L}_{\text {plant }}{ }^{-1}$ among the treatments, with water-use efficiency of $0.031 \mathrm{~kg} \mathrm{~L}^{-1}$. The greatest reductions due to the nutrient solution salinity were observed for the rind thickness and fruit mass ( 8.80 and $5.69 \%$, respectively, per unit increase in $\left.\mathrm{dS} \mathrm{m}^{-1}\right)$. The salinity of the nutrient solution did not influence the soluble solids content and fruit maturity index, but it had a negative effect on the $\mathrm{pH}$ and titratable acidity.

KEYWORDS: Citrullus lanatus L., soilless cultivation, brackish water.

\section{INTRODUCTION}

The total watermelon production in Brazil, in 2019, was 2,278,186 tons, and the Northeast region stood out with $41 \%$ of the planted area, corresponding to $34 \%$ of the national production, with a mean yield of $19.53 \mathrm{tha}^{-1}$ (IBGE 2019). However, these data refer to watermelon with $6-15 \mathrm{~kg}$.

Based on the European trend and the change in the size of households, Brazilian consumers have changed their behavior, preferring smaller fruits

\section{RESUMO}

Produção, eficiência de uso da água e qualidade póscolheita de minimelancia hidropônica sob estresse salino

Irregularidade ou escassez de chuvas nas regiões semiáridas faz com que os agricultores utilizem água de baixa qualidade na irrigação das lavouras. Objetivou-se avaliar a eficiência do uso de água e qualidade pós-colheita de minimelancia 'Sugar Baby', em resposta a diferentes condutividades elétricas da solução nutritiva [2,5 (controle); 3,5; 4,5; 5,5; e 6,5 dS m ${ }^{-1}$ ], em sistema hidropônico floating. O delineamento experimental foi o inteiramente casualizado, com quatro repetições. Avaliaram-se o consumo hídrico, produção, eficiência do uso de água e variáveis qualitativas e físico-químicas dos frutos. O consumo hídrico total das plantas durante o ciclo variou entre $43\left(6,5 \mathrm{dS} \mathrm{m}^{-1}\right)$ e $54\left(2,5 \mathrm{dS} \mathrm{m}^{-1}\right) \mathrm{L}_{\text {planta }}{ }^{-1}$ entre os tratamentos, com eficiência do uso de água de $0,031 \mathrm{~kg} \mathrm{~L}^{-1}$. As maiores reduções pela salinidade da solução nutritiva foram observadas para espessura da casca e massa dos frutos (8,80 e 5,69\%, respectivamente, por incremento unitário em dS m $\left.\mathrm{m}^{-1}\right)$. A salinidade da solução nutritiva não influenciou o teor de sólidos solúveis e índice de maturação dos frutos, porém teve efeito negativo sobre o $\mathrm{pH}$ e a acidez titulável.

PALAVRAS-CHAVES: Citrullus lanatus L., cultivo sem solo, água salobra.

(Campagnol et al. 2016). Thus, the mini watermelon has gained prominence.

In this context, the consumer market is quite demanding, choosing only fruits of excellent quality. Nowadays, the production of mini watermelon in Brazil mainly targets the export market, destined to Europe (AHB 2019).

To be able to meet this demand, in the Brazilian Northeast, due to irregularity of rains, the watermelon cultivation is only possible with the use of irrigation (Oliveira et al. 2015). Thus, many producers have

\footnotetext{
${ }^{1}$ Received: Dec. 22, 2020. Accepted: Apr. 22, 2021. Published: June 07, 2021. DOI: 10.1590/1983-40632021v5167054.

${ }^{2}$ Universidade Federal do Recôncavo da Bahia, Centro de Ciências Agrárias, Ambientais e Biológicas, Cruz das Almas, BA, Brasil.E-mail/ORCID: laisnique@hotmail.com/0000-0001-5423-9277; alidewatanabe@yahoo.com.br/0000-0003-0570-7008; marcelaganda-@hotmail.com/0000-0001-7684-673X; leiteandressa84@gmail.com/0000-0003-0682-3166; hgheyi@gmail.com/0000-0002-1066-0315.

${ }^{3}$ Universidade Federal do Recôncavo da Bahia, Centro de Ciências Exatas e Tecnológicas, Cruz das Almas, BA, Brasil. E-mail/ORCID: andre@ufrb.edu.br/0000-0002-4073-8726.
} 
used low-quality water from deep wells to meet the agricultural production (Silva Júnior et al. 2017). However, this water extracted and used for irrigation often has a high concentration of salts that usually harm crops, due to their osmotic and/or ionic effects on plants (Melo et al. 2018).

Some authors have reported the effect of water salinity on mini watermelon cultivated in soil (or substrate) and observed a reduction in plant growth and development (Ó et al. 2020, Silva et al. 2020). In an Entisol, irrigation water with electrical conductivity of up to $3.2 \mathrm{dS} \mathrm{m}^{-1}$, applied at different phenological stages, did not affect the fruit fresh mass (Silva et al. 2020). On the other hand, the cultivation of mini watermelon in substrate fertigated with nutrient solution of $6.5 \mathrm{dS} \mathrm{m}^{-1}$ of electrical conductivity reduced the fruit fresh mass by $19 \%$, without compromising its commercial quality (Ó et al. 2020). However, little is known about the cultivation of mini watermelon in hydroponic systems with brackish waters. It is worth pointing out that cultivation in hydroponic systems has been growing due to the high yield, minimization or complete elimination of the matric potential and high water-use efficiency, when compared to the conventional cultivation methods (Santos Júnior et al. 2013, Sausen et al. 2020).

Therefore, this study aimed to evaluate the production, water-use efficiency and post-harvest quality of 'Sugar Baby' mini watermelon grown in a floating hydroponic system, using brackish water to prepare the nutrient solution.

\section{MATERIAL AND METHODS}

The study was conducted in a greenhouse, in Cruz das Almas, Bahia state, Brazil (1240'19"S, $39^{\circ} 06^{\prime} 23^{\prime \prime} \mathrm{W}$ and altitude of $220 \mathrm{~m}$ ), between October and December 2018 (spring-summer). Along the experiment, the maximum and minimum mean temperatures in the greenhouse were 36.5 and $19.8{ }^{\circ} \mathrm{C}$, respectively, and the mean relative air humidity was $51 \%$.

The experimental design was completely randomized, with four replicates, resulting in a total of 20 experimental plots. Treatments consisted of five nutrient solutions with different levels of electrical conductivity (ECsol): 2.5 (control), 3.5, $4.5,5.5$ and $6.5 \mathrm{dS} \mathrm{m}^{-1}$, in a floating hydroponic system. The nutrient solutions were prepared using the formulation of Furlani et al. (1999) for fruits, with concentrations of $\mathrm{NH}_{4}-\mathrm{N}, \mathrm{NO}_{3}-\mathrm{N}, \mathrm{K}, \mathrm{P}, \mathrm{Ca}, \mathrm{Mg}, \mathrm{S}, \mathrm{B}$, $\mathrm{Cu}, \mathrm{Fe}, \mathrm{Mn}, \mathrm{Mo}$ and $\mathrm{Zn}\left(\mathrm{mol} 1,000 \mathrm{~L}^{-1}\right)$ respectively corresponding to $25.1,152.7,224.9,40.3,153.0$, $24.0,31.2,0.61,0.02,2.16,0.92,0.05$ and 0.25 . The nutrient solution in the control treatment $(\mathrm{ECsol}=$ $2.5 \mathrm{dS} \mathrm{m}^{-1}$ ) was prepared using water from the local supply system $\left(\mathrm{ECw}=0.5 \mathrm{dS} \mathrm{m}^{-1}\right)$. In the other treatments, adequate amounts of non-iodized $\mathrm{NaCl}$ were added to the solution, in order to obtain the desired ECsol level.

Sowing was performed in $0.2-\mathrm{L}$ containers with coconut fiber and one seed per container. 'Sugar Baby' mini watermelon seeds acquired from the Topseeds industry were used. Initially, the seedlings were irrigated with local supply water and, after seven days, with half-strength nutrient solution of Furlani et al. (1999). The seedlings were transplanted as they reached the first pair of true leaves (15 days after sowing) to plastic containers filled with $10 \mathrm{~L}$ of nutrient solution, in a floating hydroponic system. The solution volume was completed every day with local supply water and renewed every 10 days. The $\mathrm{pH}$ values were monitored daily and maintained at $6.0 \pm 0.5$, using $\mathrm{KOH}(1.0 \mathrm{M})$ or $\mathrm{HCl}(1.0 \mathrm{M})$ solutions. The nutrient solution was kept under intermittent aeration of 15 minutes every hour, using an air bubble stone coupled to a compressor and a timer. The spacing used was $0.50 \mathrm{~m}$ between plants and $1.0 \mathrm{~m}$ between rows.

The plants were grown and managed as described by Ó et al. (2020), with two stems, vertically trained, with one fruit per plant, and fixed between the 8 th and 10th internode. The pollination of the flowers was artificially carried out (15 days after transplanting) by taking the male flower to the female flower at dawn (between 6 and 8 a.m.). The fruits were harvested from 65 to 70 days after transplanting. The harvest point was defined when the tendril adjacent to the fruit was dry.

The analyzed variables were: water consumed by plant, fruit fresh mass, water-use efficiency, pulp fresh mass (endocarp), rind thickness, pulp yield (pulp mass/fruit mass), pulp diameter (endocarp), fruit transverse and longitudinal circumference, fruit shape index (longitudinal circumference/transverse circumference), total soluble solids, hydrogen potential $(\mathrm{pH})$, total titratable acidity and maturity index (soluble solids content/titratable acidity).

The total plant water consumption was calculated as the sum of water volumes added each 
day to the system $\left(\mathrm{L}_{\text {plant }}{ }^{-1}\right)$ along the crop cycle, with values recorded according to the water addition or solution renewal. The water-use efficiency was determined by the ratio between fruit fresh mass and water volume consumed per plant $\left(\mathrm{kg} \mathrm{L}^{-1}\right)$.

Post-harvest quality variables (soluble solids content, $\mathrm{pH}$ and titratable acidity) were determined as described by Zenebon et al. (2008). The fruit fresh mass, pulp fresh mass and rind fresh mass were determined with a semi-analytical digital scale (precision of $0.001 \mathrm{~g}$ ), while the pulp (red part of the fruit) diameter was measured with a graduated ruler and the transverse and longitudinal circumferences with a measuring tape. The thickness of the rind was measured with the aid of a measuring tape and the values expressed in $\mathrm{cm}$.

The data were subjected to analysis of variance (Anova). In the case of significant values ( $F$ test; $\mathrm{p}<0.05)$, the salinity levels, by being of quantitative nature, were subjected to polynomial regression analysis (linear and quadratic), in order to obtain the model that best fitted the data. The statistical analysis was performed using the Sisvar software, version 5.6 (Ferreira 2019).

\section{RESULTS AND DISCUSSION}

According to the results of the F test (Table 1 ), the salinity had a significant effect on fruit mass, rind thickness, pulp yield, transverse circumference, water consumption, water-use efficiency, $\mathrm{pH}$ and titratable acidity.

The increase in the ECsol linearly reduced the fruit mass by $5.70 \%$ per unit increase in $\mathrm{dS} \mathrm{m}^{-1}$ (Figure 1A). The reductions observed for fruit mass may be related to the increased salinity of the nutrient solution and reduced water potential, affecting the water uptake by plants due to the energy cost to promote osmotic adjustment (Sousa et al. 2016). $\mathrm{Cl}^{-}$and $\mathrm{Na}^{+}$ions from the nutrient solution, which are considered toxic to the plant development, may have also contributed to the reduction of fruit mass (Nascimento et al. 2015).

Sousa et al. (2016) observed a more pronounced effect of salinity on the fruit mass of 'Smile' mini watermelon, with a reduction of $8.34 \%$ per unit increase in the ECsol. On the other hand, for 'Sugar Baby' mini watermelon grown under salt stress $\left(E C s o l=6.5 \mathrm{dS} \mathrm{m}^{-1}\right)$, in coconut fiber substrate, under fertigation, Ó et al. (2020) verified a reduction of $4.2 \%$ per unit increase in the ECsol.

Leal et al. (2020) mention that the crop yields differ when they are under the same salinity level, in different cultivation systems (soil or hydroponics), and that the hydroponics technique reduces the impact of brackish water, due to the minimization of the matric potential.

It can be observed (Figure 1A) that the fruit mass was, on average, $1.74 \mathrm{~kg}$ in the treatment of lowest salinity $\left(\right.$ ECsol $\left.=2.5 \mathrm{dS} \mathrm{m}^{-1}\right)$ and $1.28 \mathrm{~kg}$ in the treatment of highest salinity $\left(\mathrm{ECsol}=6.5 \mathrm{dS} \mathrm{m}^{-1}\right)$. The fruit mass in the former case $\left(2.5 \mathrm{dS} \mathrm{m}^{-1}\right.$ treatment) is similar to that obtained by Marques et al. (2014), with the nutrient film technique hydroponic cultivation system of 'Smile' mini watermelon; and the fruit mass in the $6.5 \mathrm{dS} \mathrm{m}^{-1}$ treatment corroborates the results of Ó et al. (2020), with 'Sugar Baby' mini watermelon subjected to the same level of salinity, using coconut fiber substrate. Thus, the results of the present study are considered positive, as the mini watermelon fruits marketed in the domestic market range from 1 to $3 \mathrm{~kg}$ (Marques et al. 2014).

With regard to rind thickness, there was influence of the ECsol, which caused a linear reduction of $8.86 \%$ per unit increase in salinity (Figure 1B). Thus, the increase in salinity reduced

Table 1. Summary of the Fisher's test (F) for the analyzed fruit variables.

\begin{tabular}{|c|c|c|c|c|c|c|c|c|c|c|c|c|c|}
\hline \multirow{2}{*}{ SV } & \multicolumn{13}{|c|}{ F Test } \\
\hline & FM & RT & PY & PD & $\mathrm{TC}$ & $\mathrm{LC}$ & FSI & WC & WUE & $\mathrm{SS}$ & $\mathrm{pH}$ & TA & MI \\
\hline Salinity & $* *$ & $*$ & $*$ & $\mathrm{~ns}$ & $*$ & ns & ns & $* *$ & $* *$ & ns & $* *$ & $*$ & $\mathrm{~ns}$ \\
\hline Linear & $* *$ & $* *$ & ns & ns & $* *$ & ns & ns & $* *$ & $\mathrm{~ns}$ & $\mathrm{~ns}$ & $* *$ & $* *$ & ns \\
\hline Quadratic & ns & ns & $\mathrm{ns}$ & $\mathrm{ns}$ & ns & ns & ns & $\mathrm{ns}$ & ns & $\mathrm{ns}$ & ns & ns & ns \\
\hline Mean & 1.51 & 2.1 & 53.96 & 13.3 & 46.5 & 47.8 & 1.03 & 48.5 & 0.03 & 10.16 & 5.71 & 0.14 & 74.28 \\
\hline CV (\%) & 14.80 & 20.7 & 7.70 & 8.3 & 6.1 & 9.1 & 10.00 & 12.8 & 11.10 & 7.10 & 2.50 & 13.50 & 18.10 \\
\hline
\end{tabular}

SV: source of variation; CV: coefficient of variation; FM: fruit mass (kg); RT: rind thickness (cm); PY: pulp yield (\%); PD: pulp diameter (cm); TC: transverse circumference $(\mathrm{cm})$; LC: longitudinal circumference $(\mathrm{cm})$; FSI: fruit shape index; WC: water consumption (L plant $\left.{ }^{-1}\right)$; WUE: water-use efficiency $\left(\mathrm{kg} \mathrm{L}^{-1}\right)$; SS: soluble solids content ( ${ }^{\circ}$ Brix); pH: hydrogen potential; TA: titratable acidity ( $\%$ of citric acid); MI: maturity index (SS/TA). * Significant at $\mathrm{p} \leq 0.05 ; * *$ significant at $\mathrm{p} \leq 0.01$; ns: not significant. 

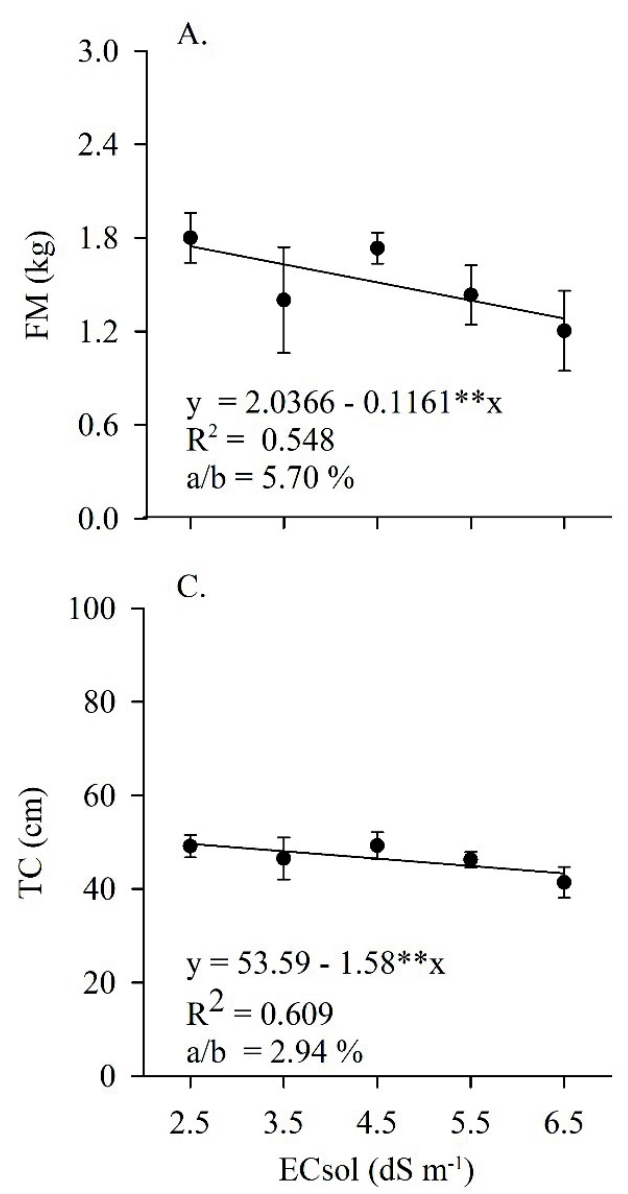
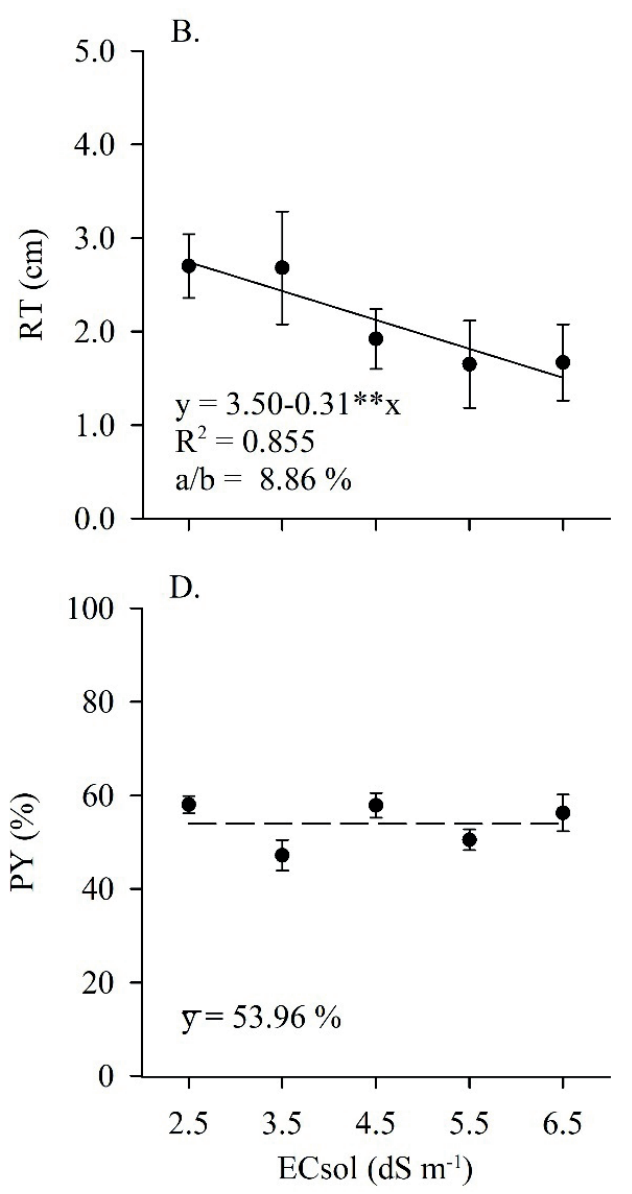

Figure 1. Fruit mass (FM; A), rind thickness (RT; B), transverse circumference (TC; C) and pulp yield (PY; D) of 'Sugar Baby' mini watermelon fruits grown in the floating hydroponic system under different electrical conductivities of the nutrient solution (ECsol). Vertical bars represent the standard deviations $(n=4)$.

the rind thickness by $45 \%$ in the $6.5 \mathrm{dS} \mathrm{m}^{-1}$ treatment $(1.5 \mathrm{~cm})$, when compared to the control treatment $(2.7 \mathrm{~cm})$.

Rind thickness in watermelon fruits is an important feature for packaging. Fruits with very thin rind require a greater care in transport to the final destination and have a shorter shelf life, an undesirable characteristic for both the trader and the final consumer (Rouphael et al. 2010).

Considering that a high salinity may cause disorders such as water deficit and nutritional imbalances (Silva Júnior et al. 2019), the reduction of rind thickness induced by salinity can be explained, at least in part, by these disorders, as reported by Azevedo et al. (2016). These authors evaluated the frequency of fertigation in 'Crimson Sweet' watermelon, in a conventional cultivation system, and observed that a higher frequency increased the rind thickness, stating that, for watermelon, this response is related to a greater availability of water and nutrients.

The transverse circumference of mini watermelon fruits decreased by $2.94 \%$ per unit increase in the nutrient solution salinity (ECsol) (Figure 1C). Thus, the mean value of transverse circumference in the control $(49.6 \mathrm{~cm})$ decreased to $43.3 \mathrm{~cm}$, in the treatment of ECsol $=6.5 \mathrm{dS} \mathrm{m}^{-1}$. Transverse circumference is an important variable in the commercialization of mini watermelon, since the consumer prefers a product with higher apparent circumference. As the longitudinal circumference of the fruits was not influenced by the nutrient solution salinity and had an average value of $47.8 \mathrm{~cm}$ ( similar to the transverse circumference), this result also indicates that the fruits showed almost a round shape.

Although influenced by the nutrient solution salinity, the pulp yield data were not described 
satisfactorily by any mathematical model, ranging from 47.18 to $58.01 \%$, with an average of $53.96 \%$ (Figure 1D). These results are very close to those found by Lima Neto et al. (2010), who reported a mean pulp yield value of $58.27 \%$, in 'Sugar Baby' mini watermelon.

With regard to pulp diameter, the mean value observed was $13.3 \mathrm{~cm}$. Fruit pulp diameter constitutes an important quality attribute, because higher values indicate a greater acceptance, due to the increase in the edible mass of the fruit. As the pulp diameter was not influenced by the ECsol, this result indicates the viability of using brackish waters in the cultivation of mini watermelon. A value identical to that found in the present study $(13.3 \mathrm{~cm})$ was also reported by Aumonde et al. (2011), who evaluated the production and quality of grafted 'Smile' mini watermelon grown in a greenhouse, under conventional irrigation.

The fruit shape index, which represents the ratio between the transverse and longitudinal circumferences, was not affected by the saline treatments (ECsol). The mean value for fruit shape index (1.03) obtained in this study indicates that the fruits showed a round or spherical shape, which is the most appreciated by the consumer market, as well as the most suitable for packaging and transportation (Barros et al. 2012).

The total water consumption per plant was significantly influenced $(\mathrm{p} \leq 0.01)$ along the cycle of the 'Sugar Baby' mini watermelon, showing reductions of $4.65 \%$ per unit increase in the nutrient solution salinity (Figure 2A). The control treatment had the highest water consumption (54.2 L plant ${ }^{-1}$ ), while the $6.5 \mathrm{dS} \mathrm{m}^{-1}$ treatment had a water consumption of $42.7 \mathrm{~L} \mathrm{plant}^{-1}$. A reduction of water consumption with the increasing of nutrient solution salinity was expected and may be explained by the difficulty in absorbing water by the roots, due to the lower osmotic potential of the solution, with consequences on the development of the shoots and root system (Silva et al. 2021).

The knowledge and quantification of water consumption by crops during their cycle is extremely relevant, especially in hydroponic systems in the semiarid regions, because these data may be used to estimate the crop water demand, a key factor for planning and selecting an adequate strategy for water use.

The water consumption values observed in the present study are much lower than those found by Marques et al. (2014), in 'Rapid Fire' (74.7 $\mathrm{L} \mathrm{plant}^{-1}$ ) and 'Smile' (73.1 L plant $\left.{ }^{-1}\right)$ mini watermelons cultivated using the nutrient film technique hydroponic system, under nutrient solution electrical conductivity of $1.9 \mathrm{dS} \mathrm{m}^{-1}$. However, it should be noted that the climatic conditions, cultivars, environment and water quality were different, and that the effect of these factors on water consumption is understandable. In addition, hydroponic systems are different; in the present study the nutrient solution
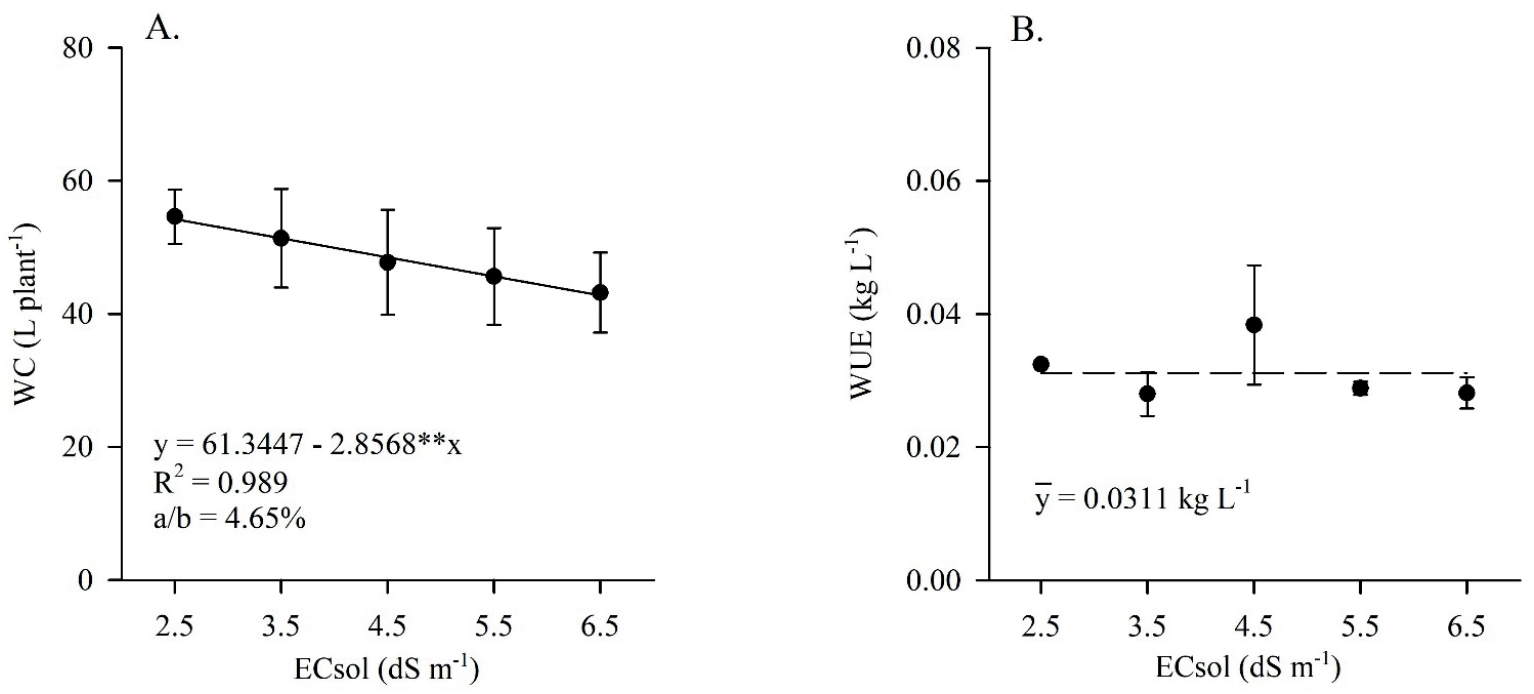

Figure 2. Total water consumption (WC; A) and water-use efficiency (WUE; B) of 'Sugar Baby' mini watermelon grown hydroponically in a greenhouse, under different electrical conductivities of the nutrient solution (ECsol). Vertical bars represent the standard deviations $(n=4)$. 
was not exposed in cultivation channels, minimizing losses through direct evaporation resulting from the wind speed or heating of the nutrient solution, as it normally occurs in the nutrient film/deep flow techniques (Ikeura et al. 2018).

The water-use efficiency values were not satisfactorily described by any mathematical model (Figure 2B), ranging from 0.027 to $0.038 \mathrm{~kg} \mathrm{~L}^{-1}$, with average value of $0.031 \mathrm{~kg} \mathrm{~L}^{-1}$. Considering that the water-use efficiency is the ratio between fruit mass and water consumption, and that both variables were affected by the ECsol, the results indicate that the effects of salinity on fruit mass and water consumption were proportionally similar. The result of the present study corroborates that reported by Marques et al. (2014) $\left(0.038 \mathrm{~kg} \mathrm{~L}^{-1}\right)$, who observed water-use efficiency in hydroponic mini watermelon using $1.9 \mathrm{dS} \mathrm{m}^{-1}$ water, indicating that the wateruse efficiency obtained in the present study was satisfactory, even with low-quality water.

The direct effects of the nutrient solution salinity on the variables $\mathrm{pH}$ and titratable acidity are shown in Figure 3. Regarding the $\mathrm{pH}$ parameter, there was a linear reduction of $1.54 \%$ per unit increase in the nutrient solution salinity. There was a reduction of $6.42 \%$ in the $\mathrm{pH}$ values between the control (5.45) and the treatment with electrical conductivity of the nutrient solution of $6.5 \mathrm{dS} \mathrm{m}^{-1}$ (5.10) (Figure 3A). According to Kyriacou et al. (2018), the pulp pH ranges from 5.5 to 5.8 in ripe watermelon, values observed only in the control treatment of the present study. A reduction in fruit $\mathrm{pH}$, as a function of salinity, was also observed in watermelon by Sousa et al. (2016).

The titratable acidity was influenced by the increase in the ECsol (Figure 3B), showing a linear increase of $10.41 \%$ per unit increase in salinity of the nutrient solution, but the values obtained in this study $\left(0.12-0.16 \mathrm{~g}\right.$ of citric acid $\left.100 \mathrm{~mL}^{-1}\right)$ are similar to those observed by Oliveira et al. (2019), in 'Boston' and 'Quetzali' watermelons. According to Kyriacou et al. (2018), the presence of acidity in the pulp is an important characteristic to maintain the organoleptic balance, giving the feeling of freshness and improving the post-harvest quality of the watermelon.

An increase in pulp acidity, in fruits grown under saline conditions, has been reported in the literature (Li et al. 2013, Sousa et al. 2016). In general, this phenomenon is explained only as an effect on concentration caused by the reduction of water content in the fruit due to salt stress. However, it has also been demonstrated that this increase may be the result of the activation of carbohydrate metabolic pathways, involving changes in the corresponding gene expression (Li et al. 2013).

There was no significant effect $(\mathrm{p}>0.05)$ on the soluble solids content in the treatments, with a mean value of $10.2^{\circ}$ Brix (Table 1). According to Lima Neto et al. (2010), an acceptable ${ }^{\circ}$ Brix for watermelon should be equal to or higher than 10 . The sugar content in the fruit is directly related to the soluble solids content, being an indicator of sweetness. Thus,
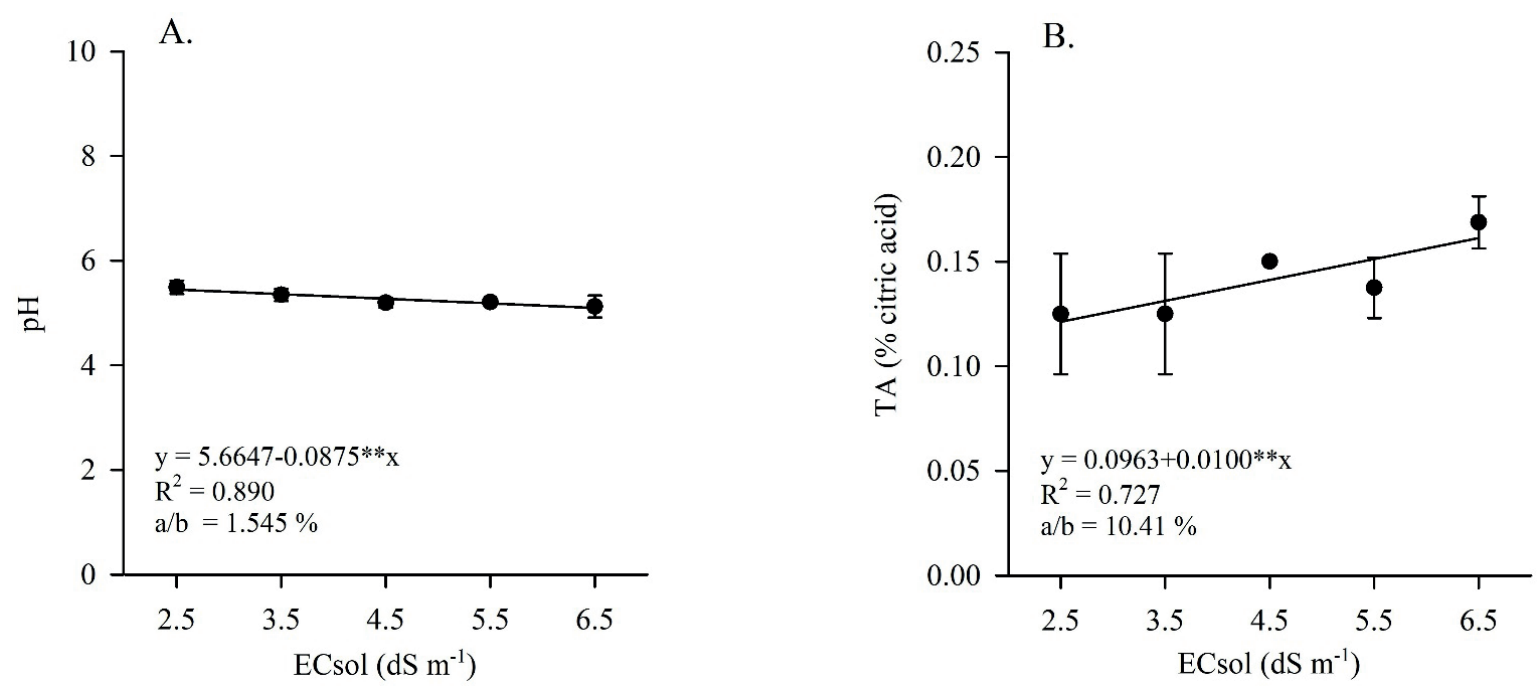

Figure 3. Hydrogen potential ( $\mathrm{pH}$; A) and titratable acidity (TA; B) of 'Sugar Baby' mini watermelon grown in a greenhouse, under different electrical conductivities of the nutrient solution (ECsol). Vertical bars represent the standard deviations $(n=4)$. 
the use of low-quality water did not alter this variable, which is of great commercial interest. Similarly, Ó et al. (2020) found no effect of the salinity of the nutrient solution on the soluble solids content of 'Sugar Baby' mini watermelon under drip irrigation and cultivated in substrate (coconut fiber + manure). However, Costa et al. (2013) observed that the soluble solids content in 'Shadow' watermelon grown in the field increased from $10.09^{\circ} \mathrm{Brix}$, at the lowest salinity of the irrigation water $\left(\mathrm{EC}=0.57 \mathrm{dS} \mathrm{m}^{-1}\right)$, to $10.35^{\circ} \mathrm{Brix}$, at the highest salinity $\left(\mathrm{EC}=4.91 \mathrm{dS} \mathrm{m}^{-1}\right)$.

The maturity index was not significantly $(p>$ 0.05 ) affected by the ECsol, with the mean value for the experiment being 74.3:1 (Table 1). The maturity index is obtained by the ratio between the soluble solids content and titratable acidity, and is the variable that best expresses the degree of fruit maturity (Lins et al. 2013). In general, the maturity index tends to increase during maturation, due to the increase in sugar concentration and reduction of acidity in the fruit pulp. The value observed in the present study is higher than the maturity index of 68.8:1 obtained by Campagnol et al. (2016), in 'Smile' mini watermelon cultivated in a greenhouse (in soil). According to the authors, a high maturity index indicates sweet fruits, and is a desirable characteristic for mini watermelon. The maintenance of the soluble solids content/ titratable acidity ratio suggests that the organoleptic quality and taste of the 'Sugar Baby' mini watermelon were not altered by salinity (Li et al. 2013).

\section{CONCLUSIONS}

1. An increase in the electrical conductivity of the nutrient solution above $2.5 \mathrm{dS} \mathrm{m}^{-1}$ reduces the fruit mass, rind thickness, pulp yield and transverse circumference of 'Sugar Baby' mini watermelon fruits, but does not compromise the other production components, such as pulp diameter, longitudinal circumference and fruit shape index;

2. The increase in the nutrient solution salinity reduces the water consumed by 'Sugar Baby' mini watermelon plants, but does not affect the wateruse efficiency;

3. The salinity of the nutrient solution increases the acidity of 'Sugar Baby' mini watermelon fruits, but does not affect the content of total soluble solids and maturity index;

4. Although the nutrient solution with electrical conductivity of up to $6.5 \mathrm{dS} \mathrm{m}^{-1}$ reduces the fruit mass, it does not compromise the pulp yield and its commercial quality, suggesting that the controlled use of brackish water for the production of mini watermelon may be viable in the semiarid region.

\section{REFERENCES}

ANUÁRIO Hortifruti Brasil (AHB). Melancia. 2019. Available at: https://www.hfbrasil.org.br/br/revista/ acessar/completo/anuario-2018-2019.aspx. Access in: Apr. 2021.

AUMONDE, T. Z.; LOPES, N. F.; PEIL, R. M. N.; MORAES, D. M.; PEDÓ, T.; PRESTES, S. L. C.; NORA, L. Enxertia, produção e qualidade de frutos do híbrido de mini melancia Smile. Current Agricultural Science and Technology, v. 17, n. 1-4, p. 1-5, 2011.

AZEVEDO, B. M.; FERNANDES, C. N. V.; NASCIMENTO NETO, J. R. do; VIANA, T. V. A.; VASCONCELOS, D. V.; FERNANDES, C. N. D. Frequency of fertirrigation with phosphate in watermelon culture productivity. Irriga, v. 21, n. 2, p. 257-268, 2016.

BARROS, M. M.; ARAÚJO, W. F.; NEVES, L. T. B. C.; CAMPOS, A. J.; TOSIN, J. M. Produção e qualidade da melancia submetida a adubação nitrogenada. Revista Brasileira de Engenharia Agrícola e Ambiental, v. 16, n. 10, p. 1078-1084, 2012.

CAMPAGNOL, R.; MATSUZAKI, R. T.; MELLO, S. C. Condução vertical e densidade de plantas de minimelancia em ambiente protegido. Horticultura Brasileira, v. 34, n. 1, p. 137-143, 2016.

COSTA, A. R. F. C.; MEDEIROS, J. F.; PORTO FILHO, F. Q.; SILVA, J. S.; COSTA, F. G. B.; FREITAS, D. C. P. Produção e qualidade de melancia cultivada com água de diferentes salinidades e doses de nitrogênio. Revista Brasileira de Engenharia Agrícola e Ambiental, v. 17, n. 9, p. 947-954, 2013.

FERREIRA, D. F. Sisvar: a computer analysis system to fixed effects split plot type designs. Revista Brasileira de Biometria, v. 37, n. 1, p. 529-535, 2019.

FURLANI, P. R.; SILVEIRA, L. C. P.; BOLONHEZI, D.; FAQUIM, V. Cultivo hidropônico de plantas. Campinas: Instituto Agronômico, 1999.

IKEURA, H.; TAKAHASHI, H.; KOBAYASHI, F.; SATO, M.; TAMAKI, M. Effects of microbubble generation methods and dissolved oxygen concentrations on growth of Japanese mustard spinach in hydroponic culture. The Journal of Horticultural Science and Biotechnology, v. 93, n. 5, p. 483-490, 2018.

INSTITUTO BRASILEIRO DE GEOGRAFIA E ESTATÍSTICA (IBGE). Produção agrícola municipal. 
2019. Available at: https://sidra.ibge.gov.br/tabela/5457. Access in: Dec. 2020.

KYRIACOU, M. C.; LESKOVAR, D. I.; COLLA, G.; ROUPHAEL, Y. Watermelon and melon fruit quality: the genotypic and agro-environmental factors implicated. Scientia Horticulturae, v. 234, n. 1, p. 393-408, 2018.

LEAL, L. Y. C.; SOUZA, E. R.; SANTOS JÚNIOR, J. A. S.; SANTOS, M. A. Comparison of soil and hydroponic cultivation systems for spinach irrigated with brackish water. Scientia Horticulturae, v. 274, e109616, 2020.

LI, X. L.; WANG, C. R.; LI, X. Y.; YAO, Y. X.; HAO, Y. J. Modifications of Kyoho grape berry quality under long-term $\mathrm{NaCl}$ treatment. Food Chemistry, v. 139, n. 1-4, p. 931-937, 2013.

LIMA NETO, I. da S.; GUIMARÃES, I. P.; BATISTA, P. F.; AROUCHA, E. M. M.; QUEIROZ, M. A. Qualidade de frutos de diferentes variedades de melancia provenientes de Mossoró - RN. Revista Caatinga, v. 23, n. 4, p. 14-20, 2010.

LINS, H. A.; QUEIROGA, R. C. F.; PEREIRA, A. M.; SILVA, G. D.; ALBUQUERQUE, J. R. T. Produtividade e qualidade de frutos de melancia em função de alterações na ralação fonte-dreno. Revista Verde de Agroecologia e Desenvolvimento Sustentável, v. 8, n. 3, p. 143-149, 2013.

MARQUES, G. N.; PEIL, R. M. N.; LAGO, I.; FERREIRA, L. V.; PERIN, L. Fenologia, consumo hídrico, rendimento e qualidade de minimelancia em hidroponia. Revista de la Faculdad de Agronomia, v. 113, n. 1, p. 57-65, 2014.

MELO, E. N.; NOBRE, R. G.; PINHEIRO, F. W. A.; SOUZA, L. de P.; LIMA, G. S.; GHEYI, H. R.; ELIAS, J. J.; SILVA, W. L. Evaluation of West Indian cherry (Malpighia emarginata) rootstock under saline water irrigation and nitrogen fertilization. Australian Journal of Crop Science, v. 12, n. 6, p. 1034-1040, 2018.

NASCIMENTO, H. H. C.; SANTOS, C. A.; FREIRE, C. S.; SILVA, M. A.; NOGUEIRA, R. J. M. C. Ajustamento osmótico em mudas de jatobá submetidas à salinidade em meio hidropônico. Revista Árvore, v. 39, n. 4, p. 641-653, 2015.

Ó, L. M. G.; COVA, A. M. W.; GHEYI, H. R.; SILVA, N. D.; AZEVEDO NETO, A. D. de. Production and quality of mini watermelon under drip irrigation with brackish water. Revista Caatinga, v. 33, n. 3, p. 766-774, 2020.

OLIVEIRA, F. A.; SÁ, F. V. S.; PAIVA, E. P.; ARAÚJO, E. B. G.; SOUTO, L. S.; ANDRADE, R. A.; SILVA, M. K. N. Emergência e crescimento inicial de plântulas de beterraba cv. Chata do Egito sob estresse salino. Agropecuária Científica no Semiárido, v. 11, n. 1, p. 1-6, 2015.
OLIVEIRA, M. M. T.; ALVES, R. E.; SILVA, L. R.; ARAGÃO, F. A. S. Fruit quality of watermelon hybrids with seeds. Revista de la Faculdad de Agronomia, v. 118, n. 1, p. 77-83, 2019.

ROUPHAEL, Y.; SCHWARZ, D.; KRUMBEIN, A.; COLLA, G. Impact of grafting on product quality of fruit vegetables. Science Horticulture, v. 127, n. 2, p. 172-179, 2010.

SANTOS JÚNIOR, J. A.; GHEYI, H. R.; GUEDES FILHO, D. H.; SOARES, F. A. L.; DIAS, N. S. Efficiency of water use in sunflower grown in hydroponic system under saline stress. Engenharia Agrícola, v. 33, n. 4, p. 718-729, 2013.

SAUSEN, D.; FERREIRA, C. R. L.; LOPES, S. C. D.; MARQUES, L. P.; SOUZA, A. J. M.; ALVES, E. C. G. A.; PATROCÍNIO, E. S. A.; CORDEIRO, K. A. S. Cultivo fora do solo: uma alternativa para áreas marginais. Brazilian Journal of Development, v. 6, n. 3, p. 1488814903, 2020.

SILVA JÚNIOR, E. G.; SILVA, A. F.; LIMA, J. S.; SILVA, M. F. C.; MAIA, J. M. Vegetative development and content of calcium, potassium, and sodium in watermelon under salinity stress on organic substrates. Pesquisa Agropecuária Brasileira, v. 5, n. 12, p. 11491157, 2017.

SILVA JÚNIOR, F. J.; SANTOS JÚNIOR, J. A.; SILVA, M. M.; SILVA, E. F. F.; SOUZA, E. R. Water relations of chives in function of salinity and circulation frequency of nutrient solutions. Revista Brasileira de Engenharia Agrícola e Ambiental, v. 23, n. 5, p. 359365, 2019.

SILVA, J. S.; SÁ, F. V. S.; DIAS, N. S.; FERREIRA NETO, M.; JALES, G.; FERNANDES, P. D. Morphophysiology of mini watermelon in hydroponic cultivation using reject brine and substrates. Revista Brasileira de Engenharia Agrícola e Ambiental, v. 25, n. 6, p. 402-408, 2021.

SILVA, S. S.; LIMA, G. S.; LIMA, V. L. A.; GHEYI, H. R.; SOARES, L. A. A.; FERNANDES, P. D. Application strategies of saline water and nitrogen doses in mini watermelon cultivation. Comunicata Scientiae, v. 11, e3233, 2020.

SOUSA, A. B. O.; DUARTE, S. N.; SOUZA NETO, O. N.; SOUZA, A. C. M.; SAMPAIO, P. R. F.; DIAS, C. T. S. Production and quality of mini watermelon cv. Smile irrigated with saline water. Revista Brasileira de Engenharia Agrícola e Ambiental, v. 20, n. 10, p. 897902, 2016.

ZENEBON, O.; PASCUET, N. S.; TIGLEA, P. Métodos físico-químicos para análise de alimentos. Campinas: Instituto Adolfo Lutz, 2008. 